\title{
Presence of Triatominae (Hemiptera, Reduviidae) and Risk of Transmission of Chagas Disease in Colima, México
}

\section{Francisco Espinoza-Gómez $/^{+}$,Arcadio Maldonado-Rodríguez, Rafael Coll-Cárdenas*, Carlos Moises Hernández-Suárez"*;, Ildefonso Fernández-Salas**:*}

Facultad de Medicina *Centro Universitario de Investigaciones Biomédicas **Facultad de Ciencias, Universidad de Colima, Av. Universidad 333, Colima, México ***Facultad de Ciencias Biológicas, Universidad Autónoma de Nuevo León, México

With the purpose of evaluating the risk of transmission of the Chagas disease in the State of Colima, México, an entomological survey was performed to obtain triatominae and the rate of infection by Trypanosoma cruzi determined by examination of its dejections. Two hundred eighteen houses located in 16 villages were sampled. In each house the intradomestic and peridomestic habitats were examined by the man-hour-house method, sensor boxes and mousebaited traps. Also, 12 silvatic places were explored around the same areas using the same techniques as the ones sampled. In total, 456 specimens were captured, of which 139 correspond to Triatoma phyllosoma pallidipennis; 80 to T. p. longipennis; one specimen of T. dimidiata and 236 nymphs of Triatoma sp. Two hundred ninety seven insects were captured in the intradomestic habitat, 132 in the peridomestic and 26 in the silvatic. The index of positive houses was $27 \%$, located in the central area of the state. The rate of natural infection with T. cruzi showed $25.6 \%$.

This results confirmed the presence of two important vectors of the Chagas disease in Colima. Its preference for the domestic habitat and its high levels of natural infection with T. cruzi suggested the existence of a significant risk for its transmission in this area of the country.

Key words: Triatoma pallidipennis - Triatoma longipennis - Trypanosoma cruzi - Chagas disease - Colima - México

In México, 27 species of triatominae (Hemiptera, Reduviidae), vectors of the American tripanosomiasis, have been described (Zarate \& Zarate 1985). In the same manner, the presence of clinical cases of Chagas disease have been recognized in several parts of the country, specially Oaxaca, Chiapas, Guerrero and Jalisco (Tay et al. 1992). It is estimated that the national level of seroprevalence is $1.6 \%$, while in the State of Colima it barely reaches $0.4 \%$ (Velasco-Castrejon et al. 1992), in such a way that Chagas disease is not considered as a public health problem in this area of the country, even though in the neighboring State of Jalisco, the illness has being fully identified and some authors calculate that its prevalence in certain communities reach 14\% (Tay et al. 1979). In this locality, at least seven species of triatomines have been described, the majority of them domiciliated and infected with Trypanosoma cruzi (Magallon et al. 1998).

Five species of triatominae have been registered in Colima: Triatoma phyllosoma pallidipennis Stål, 1872, Triatoma p. longipennis, Usinger, 1939, Triatoma $p$. picturata, Usinger, 1939, Triatoma barberi, Usinger, 1939 and Triatoma brailovsky, Martinez, 1984 (Brumpt et al. 1939, Usinger 1944, Martinez et al. 1984), as well as the presence of infected mammals with $T$. cruzi (VillaseñorMendoza 1988), which could indicate a real risk of infection for the population in this region of the country. Yet, in the quoted studies they do not indicate the presence of triatomines in the domestic habitat, nor its natural infection rate by $T$. cruzi and for more than 50 years its situation has not been re-evaluated in this region.

\footnotetext{
Research supported by Consejo Nacional de Ciencia y Tecnología (Conacyt-Simorelos Grant 9602 026).

${ }^{+}$Corresponding autor. Fax: +331-2-02-12.

E-mail: fespin@cgic.ucol.mx

Received 3 October 2000

Accepted 9 October 2001
}

The purpose of this study was to determine if the species of Triatominae originally described persisted, exploring possible factors associated with the infestation of human dwellings, its geographical distribution, its degree of association with the domestic fauna, its time of defecation and its rate of natural infection with $T$. cruzi, as a first approximation to identify the risk zones of native transmission of Chagas illness in the State of Colima.

\section{MATERIALS AND METHODS}

The State of Colima is located in the Mexican Pacific Coast at $18^{\circ} 4^{\prime} \mathrm{N}, 103^{\circ} 29^{\prime} \mathrm{W}$, with a surface of $5,540 \mathrm{~km}^{2}$ and a population of 488,028 habitants (INEGI 1998). It presents a warm semi-humid climate with mean pluvial precipitation of $980 \mathrm{~mm} /$ year. A northeast- southeastem transection was drawn following the most important commercial route of the state, where about 348,000 people live and within such a transection 16 locations were selected (Figure), six of which are urban (over 5,000 habitants) and 10 rural (less than 4,900 habitants). The altitude over the sea level along the indicated transection fluctuates between a few meters from the coast, to the south, up to 1,200 $\mathrm{m}$ in the north side of the state. The survey was carried out from September 1997 to July 1998 , the mean temperature was $25.2^{\circ} \mathrm{C}$, with a minimal daily value of $18.6^{\circ} \mathrm{C}$ during winter in Comala, and maximal of $28.7^{\circ} \mathrm{C}$ during summer in Armería. The mean pluvial precipitation was $798.5 \mathrm{~mm}$, with a a range from $658.3 \mathrm{~mm}$ in Colima city to $898.5 \mathrm{~mm}$ in Cuauhtémoc (Comisión Nacional del Agua, México).

In each locality were randomly selected, a number of houses, approximately proportional to the size of each location. The number of homes necessary to obtain an infestation probability of $20 \%$ with an absolute precision of $5 \%$, considering the large variability observed in previous studies in México (Tay et al. 1979), with a 95\% confidence level, and an estimated 80,000 houses for the area (INEGI 1998); was 246 houses. Each house was classified according to its type of construction as complete or incomplete, following Sgambatti et al. (1995) criteria. They were also 
classified according to its surroundings as clustered (when neighboring houses existed in less than $30 \mathrm{~m}$ of distance) or isolated, when the house was located outside the town. The house habitat was classified as domestic and peridomestic; in the first case, special attention was put on sleeping areas, under beds, behind furniture, on the walls and in the ceilings. In peridomestic habitat, preferably animals corrals were explored (bovines, fowls, porcine, equines and chickens), coverings, grain storages and stone fences. Finally, in each house the presence of domestic animals was consigned, either in the interior of the room, like dogs, cats or rodents, or corral animals in the patios. On the other hand, a study of the silvatic habitat was done on 12 areas located around ten selected locations, where mammal burrows were explored (rodents, armadillos and opossums), caves, tree holes, dead leaves, tree trunks and stone mounds.

The sampling technique consisted in direct search of bugs following the method proposed by Schofield (1978) of hour-man-house, in each dwelling two people were employed during $30 \mathrm{~min}$ approximately, depending on the house size. Adding to the manual collection, in 53 houses a sensor type box was placed, following specifications by Wisnivesky et al. (1987) which were left for 25 to 35 days and in 12 houses sticky, mouse baited traps were placed. For the silvatic habitat the hour-man-house search was done; plus in eight of them, sensor type boxes were placed; in seven places sticky traps were used and in seven places an UV light type trap was used overnight, during $12 \mathrm{~h}$ range.

The captured specimens were classified, according to Lent and Wygodzinsky (1979) keys. It was not possible to determine the species in the nymphs because there are not available keys for identification of T. phyllosoma complex, based on its external morphology.

Some bugs were fed with Balb-C mouse and immediately their feces were examined in search of flagellates by means of light microscope, according to the proposed method by Wisnivesky-Col1i (1982). The positive excrement were frozen at $-70^{\circ} \mathrm{C}$ for its analysis with the PCR technique with the objective of detecting a repetitive sequence of DNA in the total genome of T. cruzi of $188 \mathrm{bp}$ using the TCZ2 and TCZ3 primers, according with the Kirchhoff et al. (1996) technique.

The studied variables were: the infestation index (houses with at least one bug/total of houses examined $\mathrm{x}$ 100); density index (number of captured bugs/total of houses or places examined); colonization index (houses with at least one nymph/total of houses examined $x$ 100) and natural infection rate with T. cruzi (number of bugs with flagellates in the feces/total examined bugs). The independent variables were managed in a dichotomic form as follows: type of population (urban 0 , rural 1); house contours (clustered 0, isolated 1); type of construction (complete 0 , incomplete 1) and presence of animals in the house (no 0 , yes 1). The habitat (domestic, peridomestic or silvatic), the height of capture (over the ground, between 20 and $140 \mathrm{~cm}$, or over $145 \mathrm{~cm}$ ), and the Triatoma species were handled as stratums. The associations between the indexes and the stratums were analyzed using double and triple entrance tables, calculating $\chi^{2}$ with its respective odds ratio (OR) and its confidence interval (CI) of $95 \%$, using exact tests of Fisher and Pearson (EPIDAT 7).

The density index was also handled as a continuous proportion variable approximated to normality and that is why its differences in the different stratums was analyzed with the Student's t test. The significant statistical associations were considered when $p<0.05$. The degree of correlation between the infested houses (in dichotomic scale) with the independent categorical variables was analyzed by means of the logistic multiple regression, according to the method proposed by Hosmer and Lemeshow (1989), calculating the OR and its CI 95\% for each one of them.

\section{RESULTS}

It was only possible to obtain complete and reliable data in 218 homes of the 246 explored, and in 12 silvatic places from the 16 selected localities. At least one bug was found in 59 houses (infestation index of $27 \%$, CI 95\%: 21.3 33.4). Almost all the houses infested were located in 7 circumscribed locations in an area of $120 \mathrm{~km}^{2}$ approximately in this centrical-northern area of the state (Figure), at an altitude between 550 and $920 \mathrm{~m}$ over sea level, this same area includes four positive silvatic places of the 12 explored. Out of this region only 11 bugs were captured in two houses in the coastal location of Armeria and three in three houses in the city of Queseria. Table I shows the amount of captured specimens by locality, by habitat and by species.

Of the adult examples, 139 corresponded to $T . p$. pallidipennis, 80 to T. p. longipennis and only one to T. dimidiata var. maculipennis, Latreille, 1811. Two hundred thirty six nymphs were captured corresponding to the $T$. phyllosoma complex which species was not determined. The houses that had more than five adults were 19, of which, 18 presented examples of both species, generally in the same place of capture. The main part of domestic collecting was done in bedrooms or in the living room, on the floor, under the mattresses, off clothing, furniture or stored boxes, behind pictures on walls or in small holes. Meanwhile in the peridomestic habitat the capture predominated under rocks, bricks or wood, in dry and shaded areas, especially associated with chicken yards or rest places for dogs. In the silvatic habitat, triatomines were found only in mounds of stones, either natural or fenced.

The houses in which bugs were collected below the 20 $\mathrm{cm}$ of height were 33 (56\% positive), of the ones captured between 25 and $140 \mathrm{~cm}$ were $18(30.5 \%)$, while the ones captured over $140 \mathrm{~cm}$, were only $8(13.5 \%)$, Pearson's $\chi^{2}=$ $24.1, p=0.00002$. In no cases, bugs were found in the ceilings, even thought palm fronds ("palapa") and brick tile ("teja") roofs were explored. The most effective capture method was the manual hour-man-house, with which 439 bugs were captured, followed by mouse baited sticky trap that permitted the capture of 16 bugs, of which eight were obtained from three houses and eight in three silvatic areas. It was not possible to capture any triatominae with the sensor type boxes, nor with the UV light traps. Table II shows the correlation between the house infestation and the categorical independent variables.

The dejections of 258 insects were examined to look for flagellates, of which 66 resulted positive (natural infection rate $=25.6 \%$ ). Of 62 corresponding specimens to $T$. $p$. pallidipennis, 26 were positive $(41.9 \%)$, for which T. $p$. longipennis 42 bugs were examined resulting positive 14 $(33.3 \%)$ and of 93 nymphs, only 23 presented flagellates $(24.7 \%)$. The proportion of infected triatomines for the intradomestic habitat was $28.9 \%$; for the peridomestic $31.3 \%$ and for the silvatic $50 \%$ (three of six examined bugs). 
Urban settlement with more than three infested houses

Rural village with more than three infested houses

Urban settlement with lesse than two infested houses

$\bigcirc$ Rural village without infested houses

Positive silvatic places

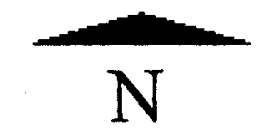

Pacific Ocean

.

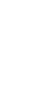

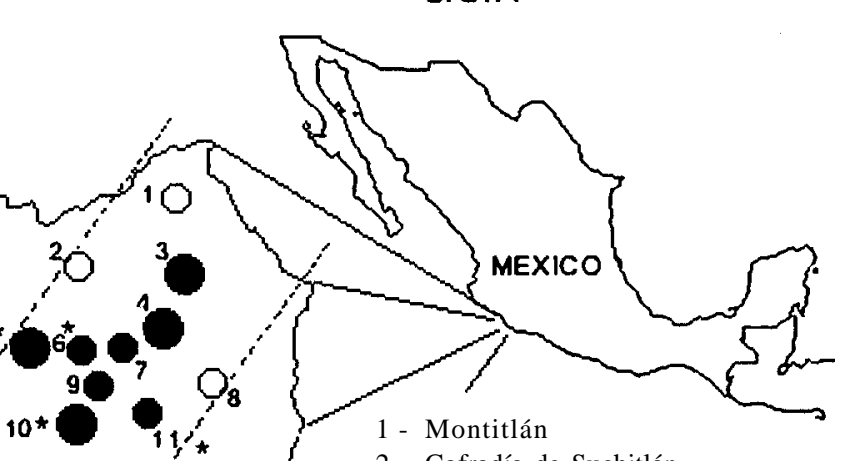

2 - Cofradía de Suchitlán

3 - Quesería

4 - Cuahutémoc

5 - Comala

6 - Nogueras

7 - Chiapa - Ocotillo

8 - Buenavista

9 - Joyitas

10 - Colima - Vila de Alvarez

11 - Trapiche

12 - Los Ortíces

13 - Armería

14 - Periquillos

15 - Flor de Coco

$30 \mathrm{~km}$

16 - Tecomán

Map of México and the State of Colima

The differences between species or different habitats did not result significant with the analysis of the $\chi^{2}$. Instead, the infection leveI of the nymphs resulted lower than the adult $\left(\chi^{2}=2.62, p=0.034\right)$.

In 60 of the positive feces to the microscope, PCR tests were done and in $52(86.6 \%)$ of them the resuIt of the electrophoresis was compatible with the $T$. cruzi species according to the proposed method by Kirchhoff et aI. (1996). Finally, in 148 bugs, it was determined the time of posprandial defecation that resulted in $21.12 \mathrm{~min}$ (CI 95\%: $18.2-24 \mathrm{~min})$

\section{DISCUSSION}

The present study confirms the presence of the T. $p$. pallidipennis and T. p. longipennis Triatominae in Colima. Both species presented a similar distribution in habitat and 8 geographical location, even more, frequently both species were found in the same group of bugs in the same house. This finding suggests a strong sympathric cohabitation that can be due to the liberation of pheromones produced by the nymphs, as demonstrated in laboratory conditions for other Triatominae (Figueiras \& Lazzari 1998). In this study, it was not possible to verify if the nymphs in both species also shared the same habitats, but the possibility exists that they equally present such sympathric coexistence.

Different to the South American species that seems to show wide distribution ranges (Lent \& Wigodzinsky 1979), T. p. pallidipennis and T. p. longipennis in Colima show a strong geographical focal point, circumscribed to an area relatively small between the cities of Colima, Comala and Cuauhtémoc.

It has not been possible to confirm in the studied area the previous register of $T$. barberi, of $T$. p. picturata, nor of T. brailovsky, quoted by Brumpt (1939), Usinger (1944) and by Zarate and Zarate (1985), this might be due to the fact that these species are still exclusively wild and can only be found in distant areas to the population. It can be also due to the extensive use of insecticides that has ocurred in the last 50 years, or also to original inadequate registration. The finding of $T$. dimidiata in Colima is unprecedented; yet, with only one sample, it could be due to accidental dragging from some nearby locality infested with this species. The previous records of Triatominae in Colima until now have been limited to the silvatic habitat; this is the first time that the presence of this insects is recognized in a clear association with the human dwelling and even more, there seems to be a tendency to infest the intradomestic habitat, as revealed by the statistical analysis of its distribution. Recently in Cuernavaca, México, the presence of $T$. $p$. pallidipennis in the interior of houses was also documented (Bautista et al. 1999). However, this tendency was not quantified in relation to the peridomestic and silvatic habitat.

On the other hand, T. p. longipennis have been found mainly in the silvatic habitat, with scarce intradomestic populations (Martínez-Ibarra et al. 2001), in contrast, we observed a significative preference for the intradomestic habitat. These findings suggest a progressive adaptation of the T. phyllosoma species to the human habitat, which could represent in the future a growing risk of transmission to the exposed populations if immediate preventive measures are not taken. Usually, no preventive measures to detect the presence of Chagas disease are carried out in Colima, nevertheless a current study for seroprevalence is being undertaken at all locations mentioned before. Furthermore, a study regarding the pathogenicity of the Colima's $T$. cruzi strain is also under development. 
TABLE I

Captured bugs by locality, species and habitat

\begin{tabular}{|c|c|c|c|c|c|c|c|c|c|c|c|}
\hline \multirow[b]{2}{*}{ Locality } & \multirow[b]{2}{*}{$\begin{array}{l}\text { Examined } \\
\text { houses }\end{array}$} & \multirow[b]{2}{*}{$\begin{array}{l}\text { Infested } \\
\text { houses }\end{array}$} & \multicolumn{3}{|c|}{ Intradomestic } & \multicolumn{3}{|c|}{ Peridomestic } & \multicolumn{3}{|c|}{ Silvatic } \\
\hline & & & $\begin{array}{c}\text { Triatoma } \\
\text { pallidipennis }\end{array}$ & $\begin{array}{c}\text { Triatoma } \\
\text { longipennis }\end{array}$ & Nymphs & $\begin{array}{c}\text { Triatoma } \\
\text { pallidipennis }\end{array}$ & $\begin{array}{c}\text { Triatoma } \\
\text { longipennis }\end{array}$ & Nymphs & $\begin{array}{c}\text { Triatoma } \\
\text { pallidipennis }\end{array}$ & $\begin{array}{l}\text { Triatoma } \\
\text { longipennis }\end{array}$ & Nymphs \\
\hline Queseria & 7 & 3 & 0 & 0 & 1 & 1 & 0 & 1 & ns & ns & ns \\
\hline Montitlán & 6 & 0 & 0 & 0 & 0 & 0 & 0 & 0 & 0 & 0 & 0 \\
\hline Buenavista & 4 & 0 & 0 & 0 & 0 & 0 & 0 & 0 & 0 & 0 & 0 \\
\hline Cofr. Suchitlán & 4 & 0 & 0 & 0 & 0 & 0 & 0 & 0 & ns & ns & ns \\
\hline Cuauhtémoc & 28 & 15 & 28 & 18 & 85 & 0 & 2 & 22 & 0 & 0 & 0 \\
\hline Chiapa Ocotillo & 13 & 5 & 4 & 1 & 5 & 1 & 1 & 5 & 1 & 0 & 2 \\
\hline Joyitas $e^{e}$ & 9 & 4 & 2 & 2 & 0 & 2 & 0 & 0 & ns & $\mathrm{ns}$ & ns \\
\hline Nogueras & 10 & 7 & 42 & 21 & 20 & 24 & 10 & 23 & 1 & 1 & 2 \\
\hline Comala & 12 & 3 & 0 & 1 & 8 & 0 & 4 & 0 & 4 & 2 & 7 \\
\hline Trapiche & 4 & 2 & 1 & 1 & 2 & 1 & 0 & 0 & ns & ns & ns \\
\hline Cd. Colima & 61 & 18 & 13 & 10 & 20 & 7 & 3 & 25 & 2 & 1 & 3 \\
\hline Ortices & 4 & 0 & 0 & 0 & 0 & 0 & 0 & 0 & 0 & 9 & 0 \\
\hline Tecomán & 12 & 0 & 0 & 0 & 0 & 0 & 0 & 0 & 0 & 0 & 0 \\
\hline Periquillos & 9 & 0 & 0 & 0 & 0 & 0 & 0 & 0 & 0 & 0 & 0 \\
\hline Flor de coco & 6 & 0 & 0 & 0 & 0 & 0 & 0 & 0 & 0 & 0 & 0 \\
\hline Armería & 29 & 2 & 4 & 2 & 5 & 0 & 0 & 0 & 0 & 0 & 0 \\
\hline Total & 218 & $59^{a}$ & 95 & 56 & 146 & $36^{b}$ & $20^{c}$ & $76^{d}$ & 8 & 4 & 14 \\
\hline
\end{tabular}

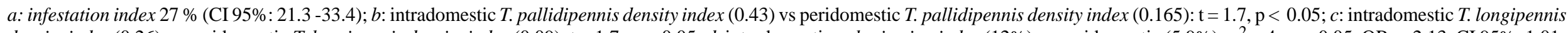
density index (0.26) vs peridomestic T. longipennis density index $(0.09), \mathrm{t}=1.7, \mathrm{p}<0.05 ;$ : intradomestic colonization index $(12 \%)$ vs peridomestic $(5.9 \%): \chi^{2}=4, \mathrm{p}<0.05$, OR $=2.13, \mathrm{CI} 95 \%: 1.01-$ $4.53 ; e$ : in Joyitas one specimen of $T$. dimidiata maculipennis was captured inside a house; ns: non sampled 


\section{T ABLE II}

Correlation of the infested houses with any type of bug (yes $=1$, no $=0$ ) and the type of town, type of construction of the house, house surroundings and the presence of animals, using multiple logistic regression in the nine positive localities to Triatoma (172 houses)

\begin{tabular}{|c|c|c|c|c|c|}
\hline Variable & $\begin{array}{l}\text { Regression } \\
\text { coefficient }\end{array}$ & $p$ value & OR & Lower $95 \%$ CI & Upper $95 \% \mathrm{CI}$ \\
\hline $\begin{array}{l}\text { Type of settlement } \\
\begin{array}{c}\text { Urban }(0), n=135 \\
\text { Rural }(1), n=37\end{array}\end{array}$ & 0.314 & 0.45 & 1.37 & 0.60 & 3.1 \\
\hline $\begin{array}{l}\text { House contour } \\
\quad \text { Clustered }(0) \mathrm{n}=125 \\
\text { Isolated (1), } \mathrm{n}=47\end{array}$ & 0.967 & 0.014 & 2.63 & 1.21 & 5.68 \\
\hline $\begin{array}{l}\text { House construction } \\
\quad \text { Complete }(0), \mathrm{n}=100 \\
\text { Incomplete (1), n=72 }\end{array}$ & -0.356 & 0.34 & 0.70 & 0.33 & 1.46 \\
\hline $\begin{array}{l}\text { Domestic animals } \\
\text { No }(0), n=51 \\
\text { Yes }(1), n=121\end{array}$ & 1.04 & 0.016 & 2.83 & 1.20 & 6.66 \\
\hline
\end{tabular}

There is a contrast with the South American species, that have a clear preference for rural houses in poor conditions of construction (Sgambatti et al. 1995). In Colima, it seems that the Triatominae prefer isolated houses, not dependent on the condition of construction of the same or to the type of community (rural or urban), judging by the logistic regression analysis. Thus, finding a plausible explanation to the fact that the new houses, that are crossing into areas previously infested by wild insect populations, are more susceptible to being colonized and that this phenomenon tends to decline, while the houses are incorporated to the urban nucleus. The same analysis detaches the presence of animals in the house favoring the infestation of triatominae, same as in South America (Gürtler et al. 1992), in such a way that it seems to be independent to the quality of the house or its location.

The Triatominae of Colima show a strong tendency to being draggers, as demonstrated by the analysis of height of the capture, which coincide with the previous findings in the laboratory for T. p. pallidipennis (Torres-Estrada et al. 1992) and contrast with the tendency of the South American species, particularly T. infestans, that frequently colonize in high parts of the house, especially the roofs constructed with blocks made of mixed mud with wood and grass (Gurtler 1992), and Rhodnius prolixus that prefers ceilings made of palm frond (Schofield 1994). These findings would have a lot of impact at the moment of planning the control campaigns in Colima, as it should take special care to the application of insecticides in the lower parts of the houses, without neglecting the higher parts of the rooms during the conventional spraying.

Regarding the capture method, it was found that the most efficient result was the hour-man-house, followed by the mouse baited trap, placed right on the floor; of which once again shows the dragging characteristic of this species and due to this they did not show any attraction to the sensor type boxes, placed on the walls, when this type of trap has demonstrated great effectiveness for T. infestans in Argentina (Wisnivesky et al. 1987). On the other hand, the bugs of Colima seem to be indifferent to the UV light, since no specimens were attracted to the light trap.
Since 1939, Brumpt et al. (1939) demonstrated the presence of $T$. cruzi in the feces of the Triatominae of Colima. However, this is the first time there was an attempt to quantify the rate of natural infection in this area. The confirmation of genome $T$. cruzi in $86 \%$ of the feces of the examined bugs by means of the PCR technique, permits us to assume that the microscopic examination of the same is sufficiently dependable to estimate the rate of natural infestation by T. cruzi, as proposed by other authors (WisniveskyColli et al. 1982, Kirchhoff et al. 1996). No significant statistical differences of infection rate were found between both species, nor between domestic and peridomestic examples, even though the nymphs did show a significant rate less than the adults, as shown by other studies (Zarate et al. 1981). The level of infection in the silvatic habitat resulted apparently higher $(50 \%)$, but the scarce obtained sample did not permit to assume a significant difference from the other two habitats. Even though that the levels of infection seem relatively low in comparison with the other species in México (Zarate et a1. 1981); in general the rates over $20 \%$ in the indigenous populations should be considered epidemically relevant, as has recently been suggested for the populations of T. p. pallidipennis in the State of Morelos (Bautista et a1. 1999), and those of T. $p$. longipennis in Ja1 isco and Nayarit (Martínez-lbarra et a1. 2001), enforcing our impression that in Colima there is a growing and still unexplored risk of transmission of Chagas disease.

\section{ACKNOWLEDGEMENTS}

To Dr Harry Brailovsky from the Instituto Nacional de Biología, Universidad Nacional Autónoma de México, who examined the specimens for taxonomic identification, and to Julio César Barragán Anaya for his enthusiastic participation in the field work.

\section{REFERENCES}

Bautista NL, Garcia de la Torre GS, de Haro Arteaga I, Salazar Schettino PM 1999. Importance of Triatoma pallidipennis (Hemiptera: Reduviidae) as a vector of Trypanosoma cruzi (Kinetoplastida: Trypanosomatidae) in the state of Morelos, México, and possible ecotopes. J Med Entomol 36: 233- 235. Brumpt E, Mazzoti L, Brumpt LC 1939. Enquetes epidé- 
miologiques sur la maladie de C. Chagas au Mexique. Reduvidés vecteurs. Animaux réservoirs de virus. Cas humains. Ann Parasitologie XVII: 300-312.

EPIDAT 7 1997. EPIDAT Program version 2.0 for Windows. Xunta of Galicia and the PAHO, Washington, DC.

Figueiras LN, Lazzari CR 1998. Aggregation behaviour and interspecific responses in three species of Triatominae. Mem Inst Oswaldo Cruz 93: 133-137.

Gürtler ER, Cecere CM, Rubel DN, Schweigmann NJ 1992. Determinants of the domiciliary density of Triatoma infestans, vector of Chagas disease. Med Vet Entomol 6: 75-83.

Hosmer DW, Lemeshow S 1989. Applied Logistic Regression, John Wiley \& Sons, New York, p. 95-97.

INEGI 1998. Anuario Estadístico dei Estado del Colima, Instituto Nacional de Geografia e Informática y Gobierno deI Estado de Colima, México.

Kirchhoff L V, Votava JR, Ochs DE, Moser DR 1996. Comparison of PCR and microscopic methods for detecting Trypanosoma cruzi. J Clin Microbiol 34: 1171-1175.

Lent H, Wygodzinsky P 1979. Revision of the Triatominae (Hemiptera, Reduviidae), and their significance as vectors of Chagas disease. Bull Amer Museum Nat History 163: 127520.

Magallón-Gastelum E, Magdaleno PN, Kaathain DG, Trujillo CF, Lozano-Kasten F, Hemandez GR 1998. Distribución de los vectores de Ia enferrnedad de Chagas (Hemiptera; Reduviidae; Triatominae) en el estado de Jalisco, México. Rev Biomed (México) 9: 151-157.

Martínez A, Carcavallo RU, Peláez D 1984. Triatoma brailovsky, nueva especie de Triatominae de México. Chagas (Argentina) 1:39-42.

Martinez-lbarra JA, Barcenas-Ortega NM, Nogueda-Torres B, Alejandre-Aguilar R, Lino Rodriguez M, Magallon-Gastelum E, Lopez-Martinez V, Romero-Napoles J 2001. Role of two Triatoma (Hemiptera: Reduviidae: Triatominae) species in the transmission of Trypanosoma cruzi (Kinetoplastida: Trypanosomatidae) to man in the west coast of México. Mem Inst Oswaldo Cruz 96: 141-144.

Schofield CJ 1978. A comparison of sampling techniques for domestic populations of triatominae. Trans $R$ Soc Trop Med Hyg 72: 949-955.
Schofield CJ 1994. Triatominae: Biologíay Control, Eurocomunica, UK, $76 \mathrm{pp}$.

Sgambatti AAL, Zicker F, de Oliveira RM, García da Silva I, Almeida S, Sgambatti AS, Martelli CM 1995. Evaluation of risk factors for house infestation by Triatoma infestans in Brazil. Am J Trop Med Hyg 53: 443-447.

Tay J, Salazar Schettino PM, Velasco Cedano M, De Haro Arteaga I, Garcia Yanez Y, Gutierrez Quiroz M 1979. Epidemiology of Chagas' disease in State of Jalisco, Republic of México. Salud Publica Mex 21: 145-149.

Tay J, Schenone H, Sanchez JT, Robert L 1992. Current status of knowledge on Chagas' disease in the Mexican Republic. Bol Chil Parasitol 47: 43-53.

Torres-Estrada JL, Martínez-lbarra JA, García-Pérez JA 1992. Influence of sex on selecting indoor resting sites by Triatoma pallidipennis Stål (Hemiptera, Reduviidae) adults under laboratory and field conditions. Universidad y Ciencia Mex 9: 44-47.

Usinger RL 1944. The Triatominae of North and Central America and West Indies and their public health significance. Public Health Bull 288: 81-83.

Velasco-Castrejon O, Valdespino JL, Tapia-Conyer R, Salvatierra B, Guzrnan-Bracho C, Magos C, Llausas A, Gutierrez G, Sepulveda J 1992. Seroepidemiología de Ia enfermedad de Chagas en México. Salud Publica Mex 34: 186-196.

Villaseñor-Mendoza MA 1988. Determinación de Reservorios de T. cruzi en un Municipio dei Estado de Colima, Thesis, U.A.M., México, 52 pp.

Wisnivesky-Colli C, Gütler RE, Solarz N, Salomon D, Ruiz A 1982. Feeding patterns of Triatoma infestans in relation to transmission of American trypanosomiasis in Argentina. $J$ Med Entomol 19: 645-654.

Wisnivesky-Colli C, Paulone I, Pérez A, Chuit R, Gualtieri J, Solarz N, Smith A, Segura E 1987 A new tool for continuous detection of the presence of triatomine bugs, vectors of Chagas disease, in rural households. Medicina 47: 45-50.

Zárate LG, Zárate R 1985. A checklist of the Triatominae (Hemiptera: Reduviidae) of México. Int J Entomol 27: 102-127.

Zárate LG, Zárate RJ, Tempelis CH, Goldsmith RS 1981. The biology and behavior of Triatoma barberi (Hemiptera, Reduviidae) in México. J Med Entomol 18: 99-106. 